\title{
REMOVAL OF CHROMIUM FROM AQUEOUS SOLUTION USING LOCALLY AVAILABLE INEXPENSIVE TARO AND WATER HYACINTH AS BIOSORBENT
}

\author{
SHAHJALAL KHANDAKER ${ }^{1}$, GaneSh ChaNdRa SAHA ${ }^{2}$, \\ AND MOHAMMAd Al MAMUn MiAH ${ }^{3}$ \\ ${ }^{1}$ Department of Textile Engineering, \\ ${ }^{2}$ Department of Civil Engineering, \\ Dhaka University of Engineering and Technology, Gazipur-1700, Bangladesh. \\ ${ }^{3}$ Roads and Highways Department, \\ Ministry of Transport and Bridges, Bangladesh.
}

s.khandaker@duet.ac.bd; ganesh@duet.ac.bd; and almamuntangail@gmail.com

(Received: 09 Jun. 2015; Accepted: 13 Oct. 2015; Published on-line: 30 Apr. 2016)

\begin{abstract}
In this investigation, locally available and inexpensive Taro and Water Hyacinth were used as biosorbents to remove chromium from synthetic wastewater. The removal of this metal ion from water in the batch and column method have been studied and discussed. Adsorption kinetics and equilibrium isotherm studies were also carried out. The material exhibits good adsorption capacity and the data follow both Freundlich and Langmuir models. Scanning Electronic Microscopic image was also used to understand the surface characteristics of biosorbent before and after biosorption studies. Effects of various factors such as $\mathrm{pH}$, adsorbent dose, adsorbate initial concentration, particle size etc. were analyzed. The initial concentrations of chromium were considered $5-30 \mathrm{mgL}^{-1}$ in batch method and only $4 \mathrm{mgL}^{-1}$ in column method. The maximum chromium adsorbed was $1.64 \mathrm{mgg}^{-1}$ and $4.44 \mathrm{mgg}^{-1}$ in Batch method and $1.15 \mathrm{mgg}^{-1}$ and $0.75 \mathrm{mgg}^{-1}$ in Column method. Batch and Column desorption and regeneration studies were conducted. Column desorption studies indicated that both of these biosorbents could be reused for removing heavy metals. Results of the laboratory experiments show that the performance of Taro and Water Hyacinth prove that they can effectively be used as low cost biosorbents for the removal of chromium from wastewater.
\end{abstract}

ABSTRAK: Dalam penyiasatan ini, tumbuh-tumbuhan tempatan yang sedia ada dan murah iaitu Taro dan Air Hyacinth telah digunakan sebagai biosorbents untuk menghapuskan kromium daripada air sisa sintetik. Penyingkiran ion logam ini daripada air dalam kaedah kumpulan dan kaedah kolum telah dikaji dan dibincang. Kajian kinetik penjerapan dan keseimbangan isoterma juga telah dijalankan. Bahan ini menunjukkan kapasiti penjerapan yang baik dan data yang diperolehi adalah saperti data dari model Freundlich dan Langmuir. Imej pengimbasan mikroskopik elektronik juga diambil untuk memahami ciri-ciri permukaan biosorbent sebelum dan selepas kajian biosorption..Kesan beberapa faktor seperti $\mathrm{pH}$, dos penjerap, kepekatan awal bahan terjerap, saiz zarah dan lain-lain telah dianalisa. Kepekatan awal kromium adalah 5-30mgL-1 dalam kaedah kelompok dan hanya 4mgL-1 dalam kaedah kolum. Kromium terjerap maksima ialah 1.64 MGG-1 dan 4.44 MGG-1 dalam kaedah kelompok dan 1.15 MGG-1 dan 0.75 MGG-1 dalam kaedah kolum. Kajian penyaherapan dan pertumbuhan semula menggunakan kaedah kelompok dan kolum telah dijalankan. Dalam kajian penyaherapan kolum menunjukkan bahawa kedua biosorbent ini boleh digunakan semula untuk menghapuskan logam berat. Hasil daripada eksperimen makmal ini menunjukkan Taro dan Hyacinth air 
adalah berkesan digunakan sebagai biosorbent kos rendah bagi penghapusan kromium dari air sisa.

KEYWORDS: Adsorption; Chromium removal; Taro; Water hyacinth; Batch method; Column studies

\section{INTRODUCTION}

Water pollution due to toxic heavy metals has been a major cause of concern for environmental engineers. The industrial and domestic wastewater is responsible for triggering severe damage to the environment and adversely affecting human health. The availability of non-biodegradable heavy metals in wastewater may lead to bioaccumulation with living organisms and may cause health complications to animals, plants and human beings [1]. Moreover, toxic heavy metals can transfer from water and soil to plants through nutrients uptake and may come into the food chain.

Chromium can be severely poisonous to both plants and animals. It is also considered one of the acute toxic metal ions for its carcinogenic nature [2]. Chromium mainly affects the liver, kidneys, and respiratory organs with hemorrhagic effects, dermatitis and ulceration of the skin due to prolonged exposure [3]. Moreover, International Agency for Research on Cancer (IARC) considered that toxic chromium can change the DNA transcription process causing important chromosome abnormalities [4]. The toxicity of chromium depends on the forms of metal, quantity, and the ionic form. Some industries discharge wastewater which contain two forms of chromium such as hexavalent and trivalent. The hexavalent form of chromium is comparatively more toxic than the trivalent form [2]. Therefore, nowadays, like other harmful heavy metals, removal of chromium from wastewater following suitable approaches is being seriously considered. Although subtraction of toxic metal ions from wastewater is a very challenging task with high treatment costs. A wide range of technologies have been established for removal of chromium from wastewater such as reverse osmosis, ion exchange, precipitation, electrolysis, adsorption, etc. [5]. Among the various treatment processes, the adsorption process is being extensively applied by numerous researchers for the removal of heavy metal from waste stream [6-8]. Adsorption is a surface phenomenon in which materials are extracted from one phase and concentrated at the surface of a second phase [34].

In the adsorption process, a considerable number of adsorbents have been investigated to remove heavy metals. These include starch xanthate [6], activated carbon [7-10], inorganic gels [11], low rank coals and related materials [12], giridih coal, singareni coal, crushed coconut shell [13], chitosan [14], peat [15], vermiculite [16], macro fungi $V$. volvacea [17], Fontinalis antipyretica biomass [18], banana peel [19], rice husk [20], etc.

In this study, attempts have been made to develop low cost bisorbents using Taro and water hyacinth for removal of chromium from wastewater. Taro and water hyacinth are locally available in Bangladesh and fast spreading, cheap biosorbents.

\section{EXPERIMENTAL STUDIES}

\subsection{Materials Preparation and Characterization}

Water hyacinth (Eichhornia crassipes) and Taro (Colocasia esculenta) were collected from in and around Dhaka University of Engineering and Technology, Gazipur, Bangladesh. The collected organisms were washed properly with deionized water to eliminate adhering foreign particles like sand and debris. The washed biomass was first air 
dried for $24 \mathrm{~h}$ and then placed in an oven at $60^{\circ} \mathrm{C}$ to constant weight. The resulting materials were grounded, powdered by Agate Mortar and sieved to the preferred particle size before usage. The material was stored in a vacuum desiccator for further use.

The water soluble matters of biosorbent was determined by taking $10 \mathrm{~g}$ of the biosorbent in contact with distilled water for $24 \mathrm{~h}$ and then biosorbent was separated from the water and dried at $40^{\circ} \mathrm{C} \pm 2^{\circ} \mathrm{C}$ for $24 \mathrm{~h}$ and weighed. Water soluble matters were reported as percentage of the original weight. Specific gravity of the biosorbent was calculated by measuring the volume of water displaced by $7 \mathrm{~g}$ of the sorbent. Mixture of biosorbent was boiled and materials were separated by filtration and then $\mathrm{pH}$ was measured by a $\mathrm{pH}$ meter (Hach, USA). Leaching characteristics were undertaken by conducting a leachability test and chemical oxygen demand (COD) was determined as per standard methods. Moreover, biosorbents were characterized by scanning electronic microscope (SEM) before and after chromium sorption.

\subsection{Batch Method Adsorption Studies}

\subsubsection{Kinetics of Adsorption}

Batch method was used for kinetics studies. Five hundred milliliters of chromium solution (5 mgL $\mathrm{m}^{-1}, 10 \mathrm{mgL}^{-1}, 15 \mathrm{mgL}^{-1}, 20 \mathrm{mgL}^{-1}, 25 \mathrm{mgL}^{-1}$, and $30 \mathrm{mgL}^{-1}$ ) was taken in 1 $\mathrm{L}$ beaker. The exact initial concentration of chromium in solution was measured by atomic absorption spectrometer (AA-7000, Shimadzu, USA) before starting the experiment. Biosorbents $\left(2 \mathrm{gL}^{-1}\right)$ were added and the solution was stirred $(120 \mathrm{rpm})$ by a rotary shaker and the residual heavy metal concentration in solution was measured by taking $5 \mathrm{~mL}$ aliquots from the solution at predetermined contact time ( $5 \mathrm{~min}, 10 \mathrm{~min}, 15 \mathrm{~min}, 30 \mathrm{~min}, 45$ min, $60 \mathrm{~min}, 90 \mathrm{~min}, 120 \mathrm{~min}, 180 \mathrm{~min}, 200 \mathrm{~min}, 300 \mathrm{~min}$ ). However, among the initial kinetics studies, the equilibrium time of $3 \mathrm{~h}$ was found to be sufficient for the observed metal concentrations.

The adsorption was estimated by employing the following expression [21]:

$\%$ removal $=\left(\frac{\mathrm{Co}-\mathrm{C} e}{\mathrm{Co}}\right) \times 100$

where, $\mathrm{C}_{0}=$ initial chromium concentration and $\mathrm{C}_{\mathrm{e}}=$ Chromium concentration at equilibrium condition.

\subsubsection{Effect of pH and Biosorbent Dose upon Adsorption}

The effects of solution $\mathrm{pH}$ on adsorption of chromium were investigated over a range of 3 to 10 and the $\mathrm{pH}$ was adjusted by $0.1 \mathrm{~N} \mathrm{HNO}_{3}$ and $0.1 \mathrm{~N} \mathrm{NaOH}$. Contact time was chosen as $3 \mathrm{~h}$ to study the effect of $\mathrm{pH}$ at room temperature $\left(25^{\circ} \mathrm{C}\right)$. Moreover, the effect of biosorbent on chromium removal was studied with varying biosorbent dose from 1 to $5 \mathrm{gL}^{-}$ ${ }^{1}$ in a $4 \mathrm{mgL}^{-1}$ of chromium solution.

\subsubsection{Batch mode desorption studies}

Batch desorption studies were conducted to verify the possibility of reusing the biosorbent. After $3 \mathrm{~h}$ contact time, biosorbent was separated from solution by using Whatman filter paper and washed with distilled water to remove unadsorbed chromium and oven dried. The dried biosorbent was again reused maintaining a $2 \mathrm{gL}^{-1}$ concentration for 3 h.

\subsection{Fixed Bed Column Studies}

Column studies (down flow mode) were conducted with distilled water spiked metals. A $63.15 \mathrm{~mm}$ ID glass column was filled with the biosorbent. A bed depth of $80 \mathrm{~mm}$ was adopted and a study bed depth of $100 \mathrm{~mm}$ was maintained. Porous stone was used to support 
the biosorbent in the column. Influent concentration was $4 \mathrm{mgL}^{-1}$. The samples from effluent were collected periodically (15 to $30 \mathrm{~min}$ interval) and tested for metal concentration. The columns were run up to $3 \mathrm{~h}$. Column desorption studies were also performed in the same column and with the same biosorbent that was saturated with metal. After exhaustion of the column, the biosorbent was separated and washed with distilled water. The same biosorbent was utilized again in the column for desorption using $0.01 \mathrm{~N} \mathrm{HNO}_{3}$.

\section{RESULTS AND DISCUSSIONS}

\subsection{Characteristics of the adsorbents}

The water soluble matters were $96 \%$ and $44 \%$ in Taro and water hyacinth respectively. The specific gravity of Taro was 0.70 , whereas in water hyacinth this was 0.35 . pH was measured in water hyacinth and Taro were 4.80 and 3.90 and leaching as COD was 2094 $\mathrm{mgL}^{-1}$ and $5262 \mathrm{mgL}^{-1}$ respectively.

SEM studies were performed to understand the physical nature and physical damage of biosorbent surface during adsorption. The SEM pictures of biosorbent Taro and water hyacinth before and after chromium uptake are shown in Fig. 1(a), 1(b), 2(a), and 2(b). The images clearly indicate that the biosorbents are highly porous in nature which is a desirable characteristic of any adsorbent.

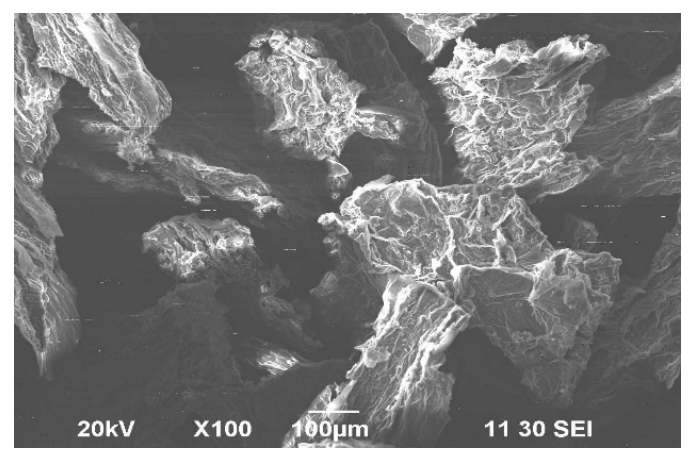

Fig. 1 (a): Scanning Electron Micrograph of Taro.

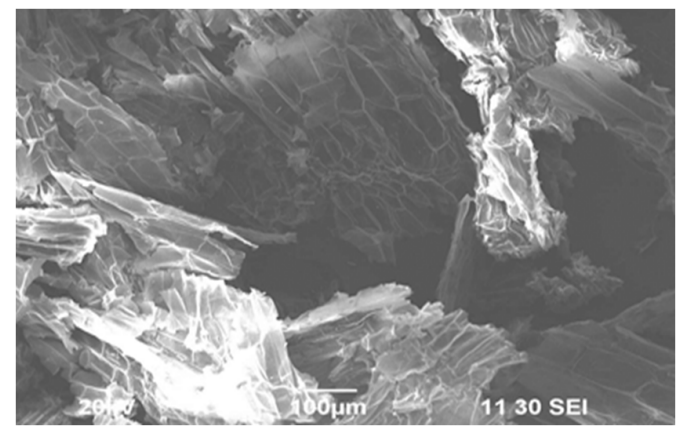

Fig. 2 (a): Scanning Electron Micrograph of water hyacinth.

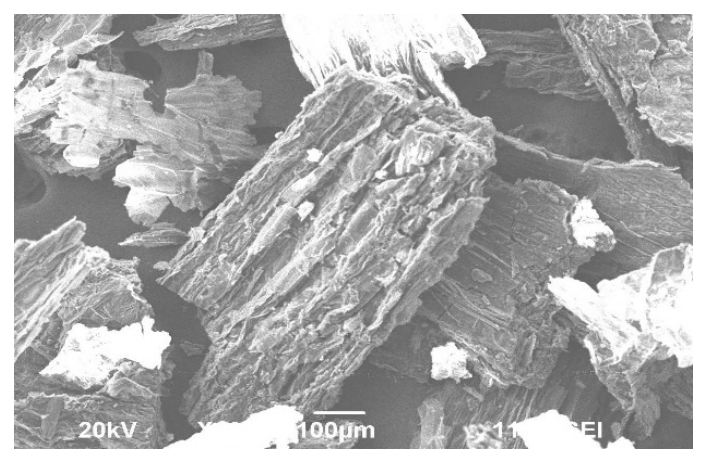

Fig. 1 (b): Scanning Electron Micrograph of $\mathrm{Cr}$ adsorbed Taro.

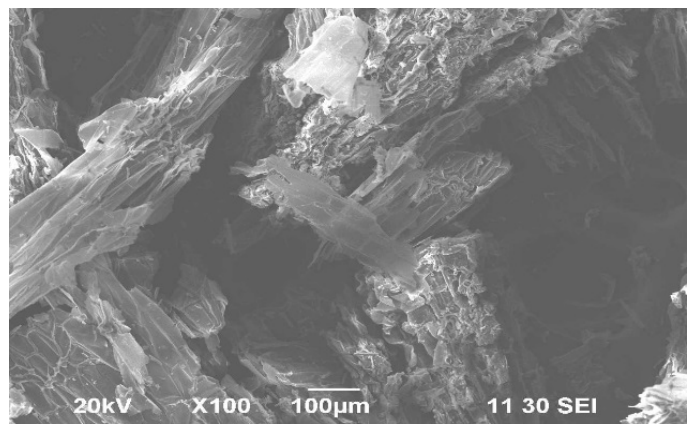

Fig. 2 (b): Scanning Electron Micrograph of $\mathrm{Cr}$ adsorbed water hyacinth. 


\subsection{Effect of Particle Size}

Three different particles mean sizes such as $0.945 \mathrm{~mm}, 0.505 \mathrm{~mm}$ and $0.150 \mathrm{~mm}$ were considered for batch adsorption investigation. Chromium uptake by the biosorbents for their different sizes with time is shown in Fig. 3 and Fig 4. The adsorption rates were initially rapid because of readily accessible sites for exchange adsorption. Maximum $\mathrm{Cr}$ uptake was observed by the sorbent mean size $0.505 \mathrm{~mm}$ for both Taro and water hyacinth. Therefore, the sorbent mean size $0.505 \mathrm{~mm}$ was considered for further experimentation.

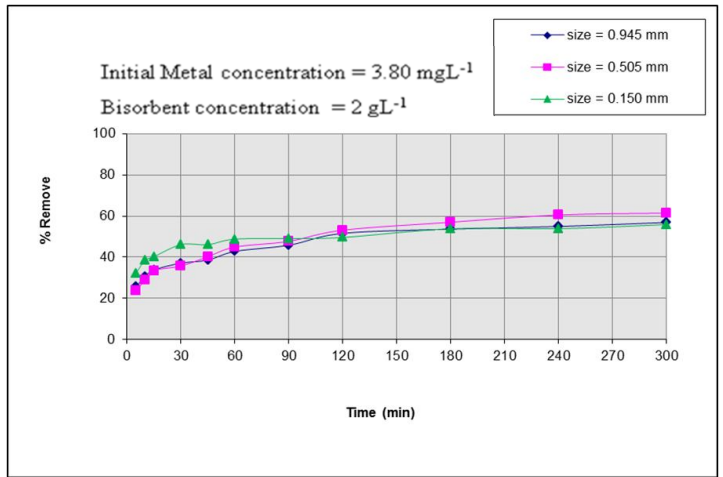

Fig. 3: Cr removal kinetics for different sizes of Taro.

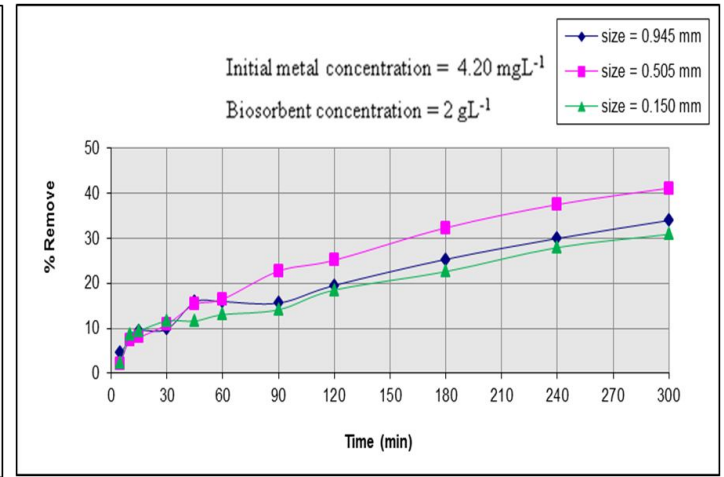

Fig. 4: Cr removal kinetics for different sizes of water hyacinth.

\subsection{Effect of Adsorbate Initial Concentration}

The metal removal efficiency is marginally increased for solution with same initial metal concentrations for any contact period. The variations of chromium uptake by the biosorbent for different initial $\mathrm{Cr}$ concentrations with time are shown in Fig. 5 and Fig. 6. Metal uptake often follows a two-step kinetics [22]. The same phenomenon was observed in the present studies. The adsorption rates were initially rapid because of higher number of available accessible sites for exchange adsorption, and due to the presence of higher solute concentration gradient. Nearly $3 \%, 9 \%, 14 \%, 20 \%, 25 \%, 30 \%$ of total sorption at initial stage for metal concentrations of $5 \mathrm{mgL}^{-1}, 10 \mathrm{mgL}^{-1}, 15 \mathrm{mgL}^{-1}, 20 \mathrm{mgL}^{-1}, 25 \mathrm{mgL}^{-1}, 30 \mathrm{mgL}^{-}$ ${ }^{1}$ respectively by Taro. It is seen that the total sorption has been completed in around 60 min.

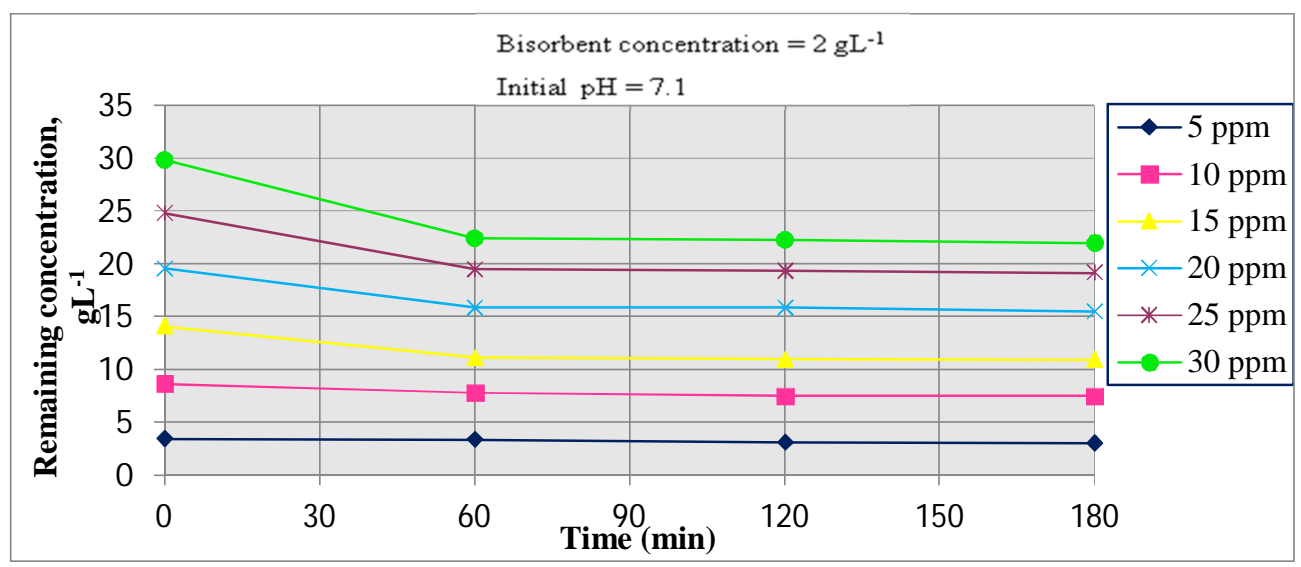

Fig. 5: Bisorption kinetics of $\mathrm{Cr}$ with different initial concentrations by Taro. 


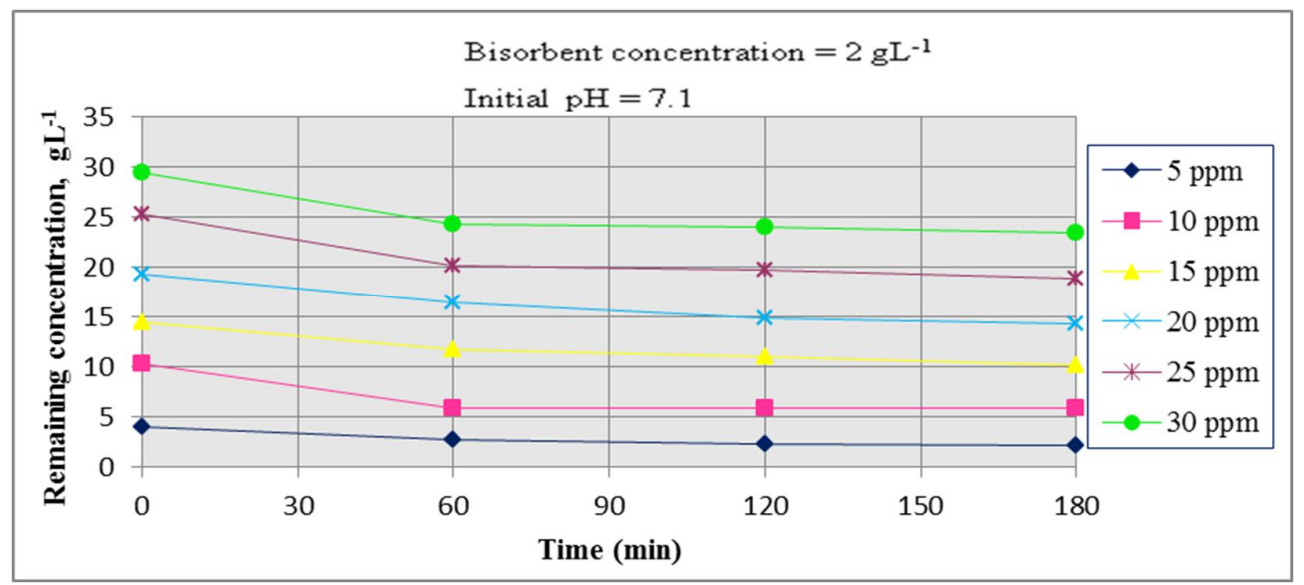

Fig. 6: Bisorption kinetics of $\mathrm{Cr}$ with different initial concentrations by water hyacinth.

On the other hand, at the beginning about $4 \%, 11 \%, 14 \%, 19 \%, 25 \%, 30 \%$ of total sorption were for the $\mathrm{Cr}$ concentration of $5 \mathrm{mgL}^{-1}, 10 \mathrm{mgL}^{-1}, 15 \mathrm{mgL}^{-1}, 20 \mathrm{mgL}^{-1}, 25 \mathrm{mgL}^{-}$ ${ }^{1}, 30 \mathrm{mgL}^{-1}$ respectively by water hyacinth and virtually the sorption process was completed within $60 \mathrm{~min}$.

The uptake capacity increases with increase in initial concentration, which may be due to the availability of more number of Cr (VI) ions in solution for adsorption. Moreover, higher initial adsorbate concentration provided greater driving energy to overcome various mass transfer confrontations of the metal ions from the aqueous to the solid phase resulting in higher probability of collision between $\mathrm{Cr}$ (VI) ions and the active sites [23].

\subsection{Equilibrium Studies}

When an adsorbent is in contact with an adsorbate, an apparent equilibrium is established between the adsorbate concentration in the liquid phase and that on the solid phase. This state is one of dynamic stability. The amount of adsorbate migrating onto the adsorbent is counterbalanced by the amount of adsorbate migrating back into the solution phase and should not be construed as a state of termination of adsorption. The adsorption equilibria can hence be modelled along the lines of a heterogeneous chemical reaction. Langmuir and Freundlich isotherms are widely used as equilibrium isotherm models to represent experimental data obtained from batch equilibrium studies [24].

\subsubsection{Langmuir Isotherm}

The Langmuir theory shows controlling of extreme sorption abilities which denotes the first theoretical treatments of non-linear sorption, and has been effectively applied to an extensive range of systems [25]. The model assumes uniform energies of adsorption onto the surface and no transmigration of the adsorbate in the plane of the surface. Graphically, it is represented by a plateau, an equilibrium saturation point where once a molecule conquers a site, no additional adsorption can happen [26-27]. The Langmuir isotherm is presented by the following equation:

$$
q_{e}=\frac{Q \max b C e}{1+b C e}
$$

Where $Q_{\max }$ and $b$ are Langmuir constants related to maximum adsorption ability and energy of adsorption respectively [28]. $q_{e}$ is the amount adsorbed $\left(\mathrm{mgg}^{-1}\right) ; C_{e}$ is the equilibrium concentration of the adsorbate $\left(\mathrm{mgL}^{-1}\right)$. 
When $\frac{1}{q e}$ is plotted against $\frac{1}{C e}$, a straight line with slope is obtained. Figure 7 and 8 show the adsorption isotherm of $\mathrm{Cr}$ for Taro and water hyacinth respectively. The value of the correlation coefficient $\mathrm{R}^{2}$ suggests that adsorption of chromium follows the Langmuir isotherm. Langmuir constants $b, Q_{\max }$ and $\mathrm{R}^{2}$ value are given in Table 1.

Table 1: Langmuir isotherm coefficients

\begin{tabular}{cccccc}
\hline Metal & Name of Biosorbent & Biosorbent Size (mm) & $\begin{array}{c}\boldsymbol{Q}_{\max } \\
\left(\mathbf{m g ~ g}^{-1}\right)\end{array}$ & $\boldsymbol{b}$ & $\mathbf{R}^{\mathbf{2}}$ Value \\
\hline \multirow{2}{*}{ Chromium } & Taro & 0.505 & 1.64 & 0.03 & 0.99 \\
& \multirow{2}{*}{ Water hyacinth } & 0.505 & 4.44 & 0.11 & 0.96 \\
\hline
\end{tabular}

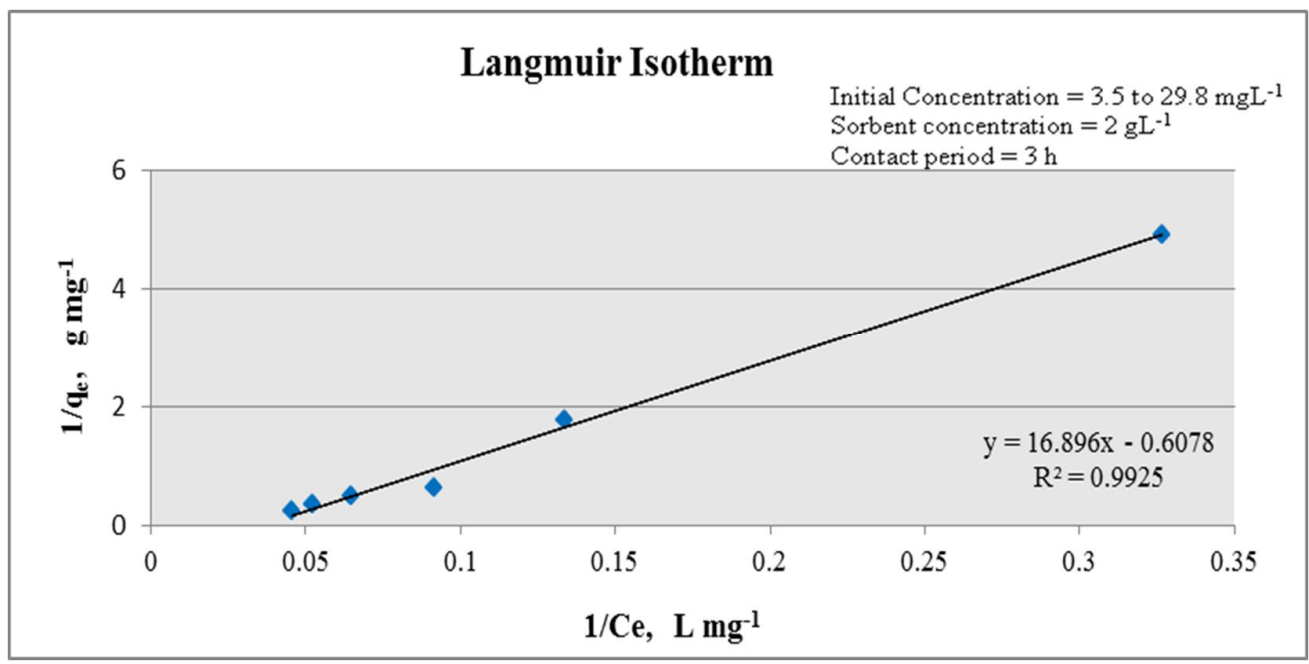

Fig. 7: Adsorption Isotherm of $\mathrm{Cr}$ absorbed onto Taro.

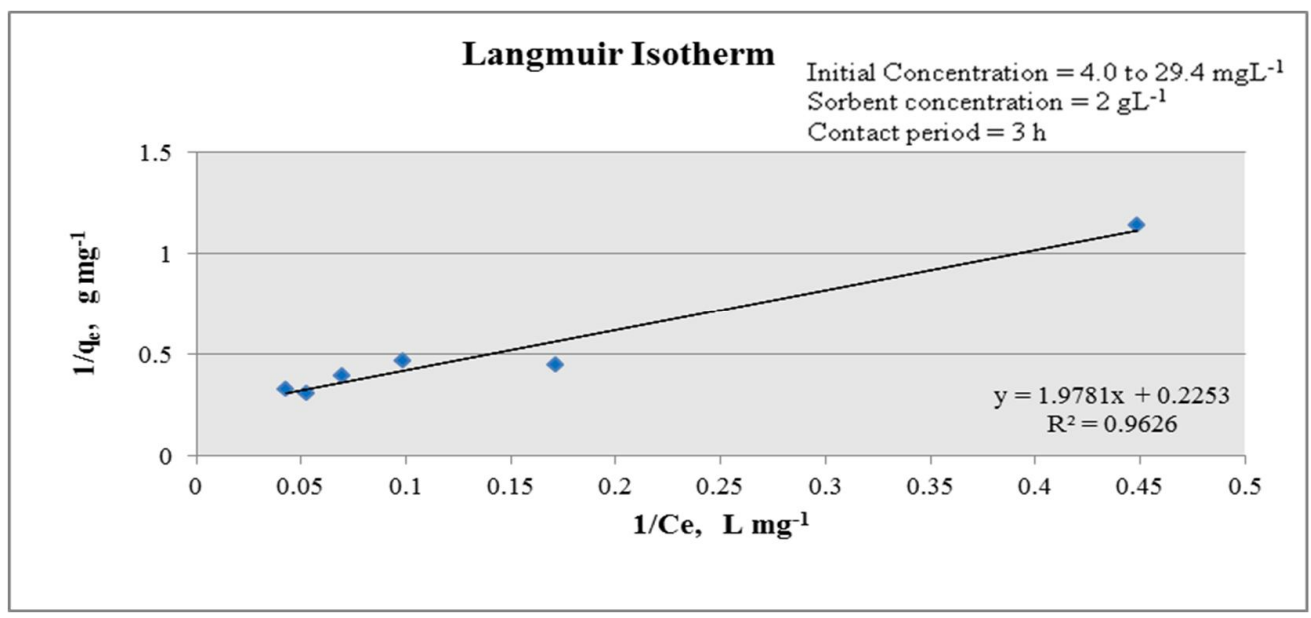

Fig. 8: Adsorption isotherm of $\mathrm{Cr}$ absorbed onto water hyacinth.

\subsubsection{Freundlich Isotherm}

The adsorption data of chromium were also analyzed by the Freundlich model. The linear form of Freundlich equation may be written as 
$\log \left(q_{e}\right)=\log \left(K^{\prime}\right)+(1 / n) \log \left(C_{e}\right)$

Where $\mathrm{q}_{\mathrm{e}}$ is the amount adsorbed $\left(\mathrm{mgg}^{-1}\right), C_{e}$ is the equilibrium concentration of the adsorbate $\left(\mathrm{mgL}^{-1}\right)$, and $K^{\prime}$ and $n$ are Freundlich constants connected to adsorption capability and adsorption concentration, respectively [29]. When $\log \left(q_{e}\right)$ is plotted against $\log \left(C_{e}\right)$, a straight line with slope $1 / n$ is obtained which shows that the adsorption of chromium follows a Freundlich isotherm (Fig. 9 and Fig. 10), and values of $K^{\prime}$ and $n$ are shown in Table 2.

Table 2: Freundlich isotherm coefficients

\begin{tabular}{cccccc}
\hline Metal & Name of Bisorbents & Biosorbent Size $(\mathbf{m m})$ & $\boldsymbol{K}^{\prime}\left(\mathbf{m g ~ g}^{-1}\right)$ & $\boldsymbol{n}$ & $\mathbf{R}^{2}$ Value \\
\hline \multirow{2}{*}{ Chromium } & Taro & 0.505 & 28.44 & 0.66 & 0.98 \\
& Water hyacinth & 0.505 & 1.47 & 1.96 & 0.88 \\
\hline
\end{tabular}

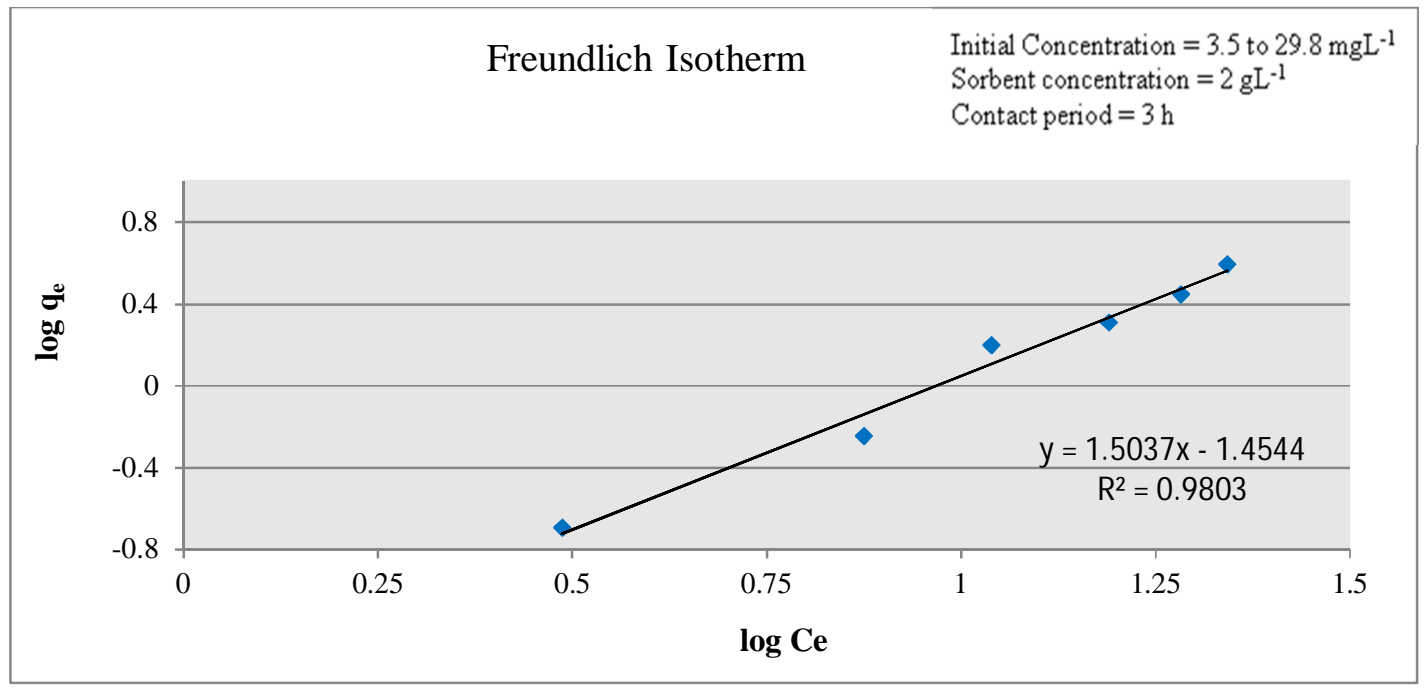

Fig. 9: Adsorption isotherm of $\mathrm{Cr}$ absorbed by Taro.

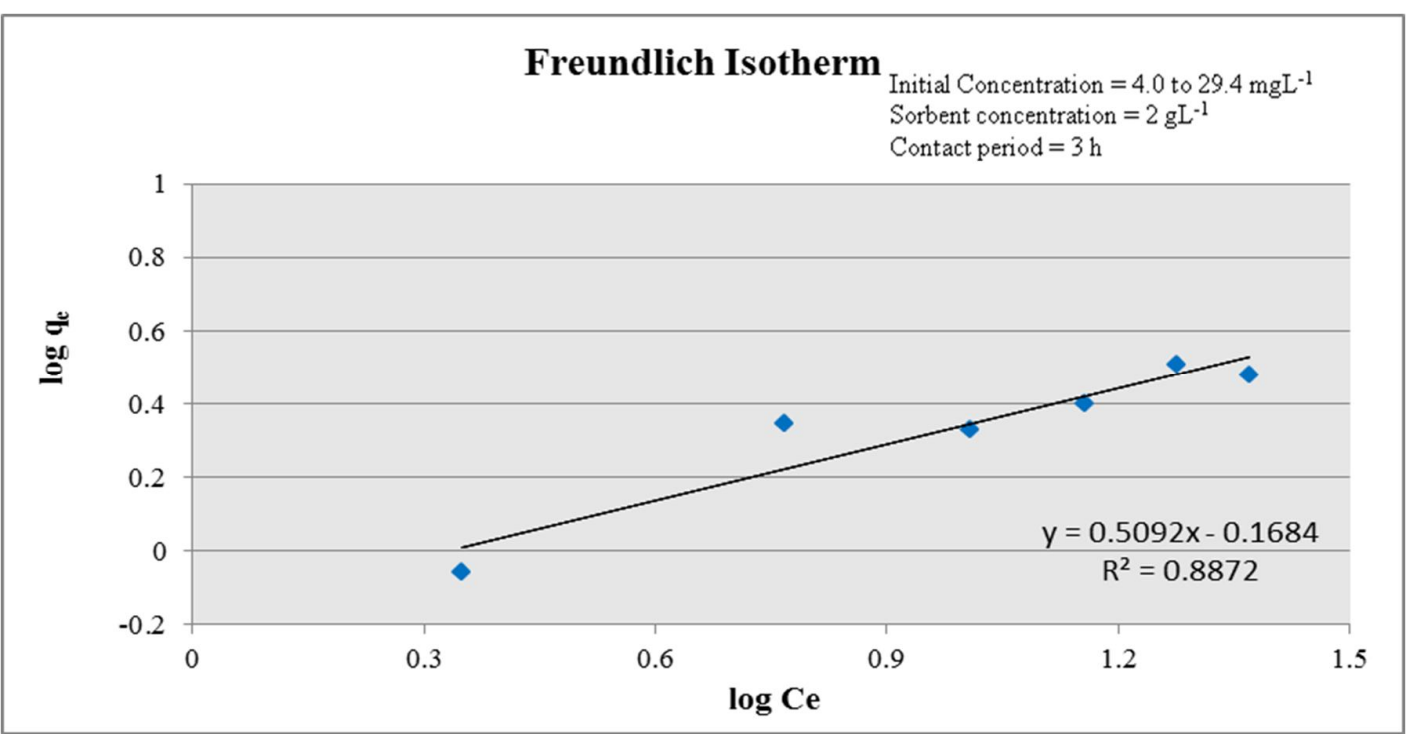

Fig. 10: Adsorption isotherm of $\mathrm{Cr}$ absorbed by water hyacinth. 


\subsection{Effect of pH}

The $\mathrm{pH}$ of the solution is an important factor which influences the uptake of metal ions by biosorbents in many ways. The effect of $\mathrm{pH}$ on metal adsorption is given in Fig. 11 and Fig. 12. The maximum uptake of chromium took place at $\mathrm{pH} 4.5$ and 3.0 by Taro and Water Hyacinth respectively. It is also apparent from the figures that the removal of chromium decreases from $19 \%(\mathrm{pH} 4.5)$ to $10 \%(\mathrm{pH} \mathrm{6.0)}$ ) and then increases to $15 \%(\mathrm{pH} \mathrm{10.0)}$ ) for Taro whereas for water hyacinth it is declined from $34 \%(\mathrm{pH} 3.0)$ to $10 \%(\mathrm{pH} 10)$. Moreover, a similar trend for $\mathrm{Cr}$ (VI) adsorption on activated carbon is described by Mohammad et al. [30].

The higher adsorption of $\mathrm{Cr}$ by Taro and water hyacinth at low $\mathrm{pH}$ might be due to the neutralization of surface charge by a surplus of hydrogen ions. Therefore, smoothing the diffusion of dichromate ions and their adsorption on the prepared adsorbent [31]. Higher adsorption of chromium at low $\mathrm{pH}$ values might suggest that the mechanism of metal ion uptake is highly energetic to overcome the net electrostatic repulsion.

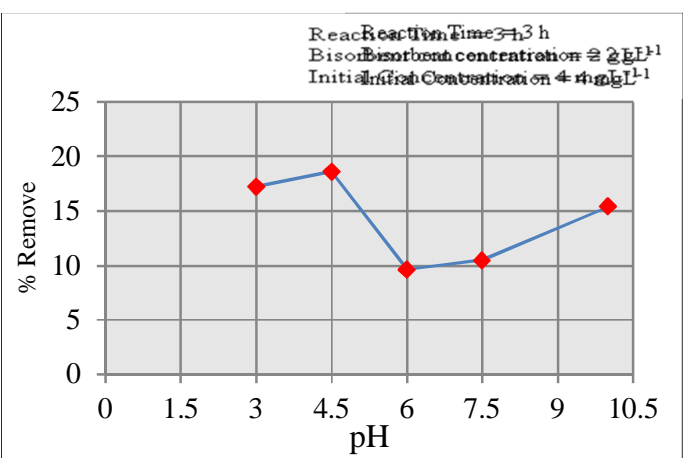

Fig. 11: Effect of $\mathrm{pH}$ of adsorbate solution on Cr by Taro.

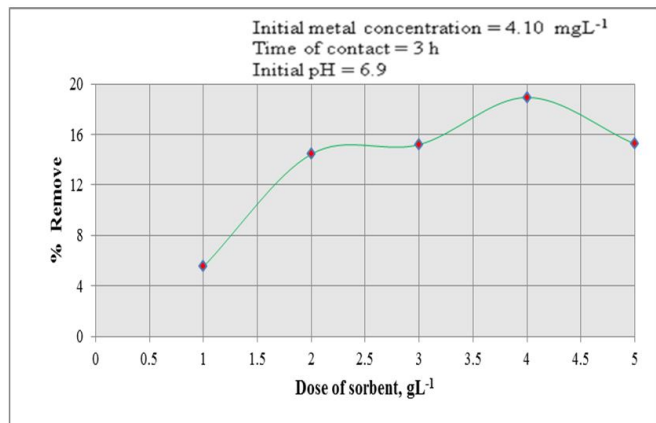

Fig. 13: Effect of Taro concentration on Cr removal.

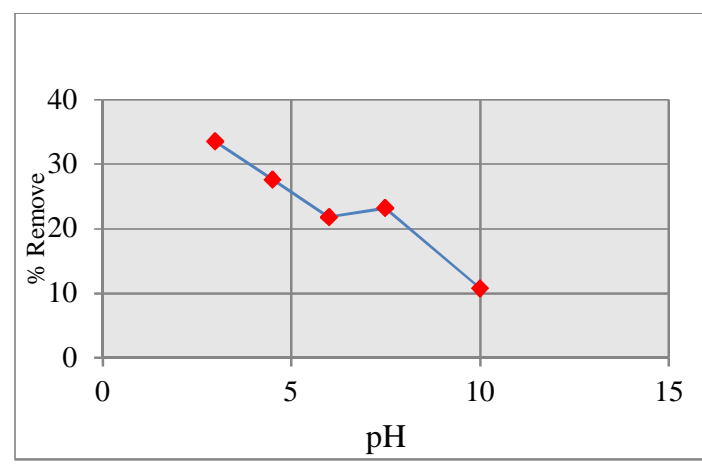

Fig. 12: Effect of $\mathrm{pH}$ of adsorbate solution on $\mathrm{Cr}$ by water hyacinth.

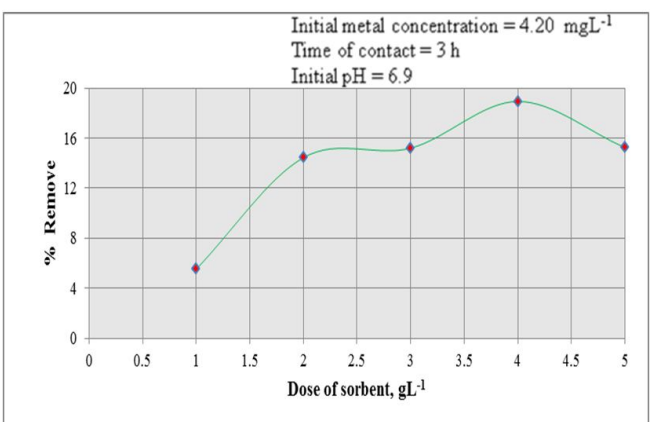

Fig. 14: Effect of water hyacinth concentration on Cr removal.

\subsection{Effect of Biosorbent Concentration}

The selected adsorbents were used at concentrations ranging from 1.0 to $5.0 \mathrm{gL}^{-1}$ in batch adsorption method at $25^{\circ} \mathrm{C}$. The $\mathrm{Cr}$ uptake is found to increase rapidly with increasing concentration of biosorbent Taro up to a dose of $4 \mathrm{gL}^{-1}$ and for water hyacinth up to $3 \mathrm{gL}^{-1}$ (Fig. 13 and Fig. 14) The number of available sites and exchanging ions for adsorption depends upon the amount of adsorbent in the adsorption process. The increase in the 
removal efficiency can be attributed to the increased number of sites and exchangeable ions available for adsorption [30].

\subsection{Batch desorption studies}

The desorption studies have been performed for $\mathrm{Cr}$ using distilled water for both biosorbents and the results are presented in Fig. 15 and Fig. 16. It is clearly seen in figures that a marginal amount of chromium desorbed and there is some scope to further reuse these biosorbent for heavy metal removing.

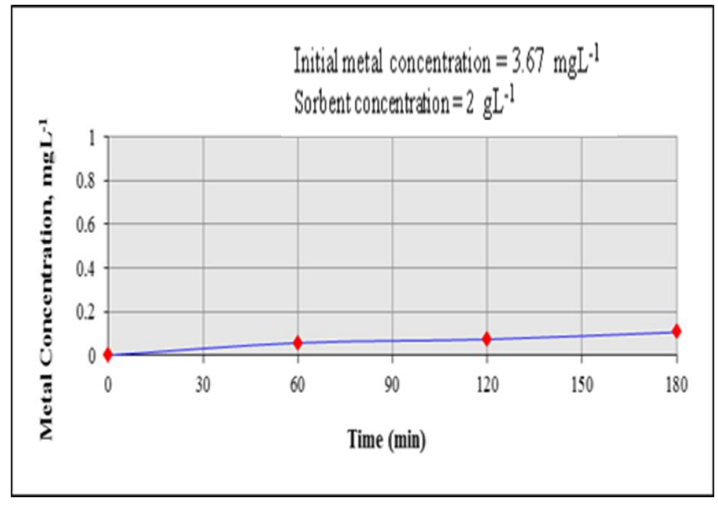

Fig. 15: Cr desorption kinetics with adsorbed biosorbent Taro.

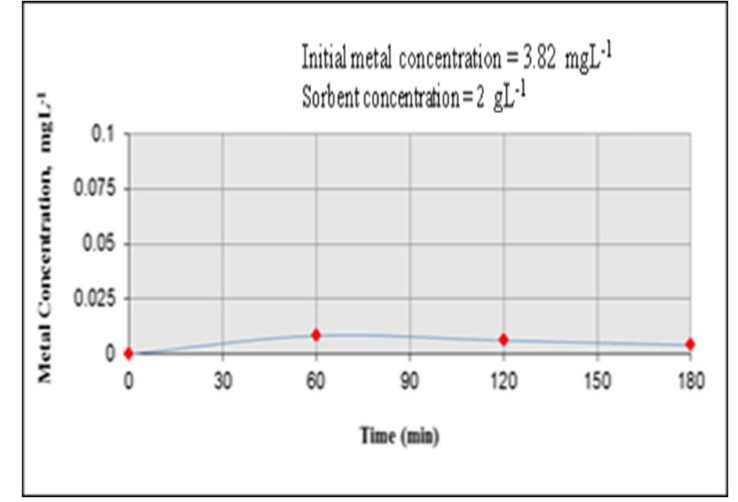

Fig. 16: Cr desorption kinetics from adsorbed biosorbent water hyacinth.

\subsection{Column Kinetic Study}

The Thomas model was used to analyze the column performance. The linearized form of the Thomas model is given below [32]:

$$
\ln \left(\frac{C_{0}}{C_{e}}-1\right)=\frac{k_{T} q_{0} M}{Q}-\frac{k_{t} C_{0}}{Q} V
$$

Where $C e, C o=$ the effluent and inlet solute concentrations $\left(\mathrm{mgL}^{-1}\right), q_{o}=$ the maximum adsorption capacity $\left(\mathrm{mgg}^{-1}\right), \mathrm{M}=$ the total mass of the adsorbent $(\mathrm{g}), Q=$ volumetric flow rate $\left(\mathrm{ml} \mathrm{min}^{-1}\right), V=$ the throughput volume $(\mathrm{ml})$ and $k_{T}=$ the Thomas rate constant $(\mathrm{ml} \mathrm{min}-$ $\left.{ }^{1} \mathrm{mg}^{-1}\right)$.

The kinetic coefficient, $k_{T}$ and the adsorption capacity of the bed, $q_{o}$ were determined from the plot of $\ln \left(\frac{C o}{C e}-1\right)$ against $V$ (Fig. 17 and Fig. 18). Thomas rate constant, $k_{T}$ is dependent on flow rate, initial ion concentration and bed height. The maximum adsorption capacity, $q_{o}$ is increased with increase in flow rate and initial ion concentration but decreased with increase in bed height. The values of $k_{T}$ obtained in this work are similar to the ones obtained by Sivakumar and Palanisamy [33]. The value of regression coefficient $\left(\mathrm{R}^{2}\right)$ indicates that the kinetic data conformed well to Thomas model.

Figure 17 shows the results of the column study with distilled water spiked with chromium by biosorbent Taro. Column exhaustive capacity of distilled water spiked chromium shows values $1.15 \mathrm{mgg}^{-1}$. Figure 18 shows the results of column study with distilled water spiked with chromium by water hyacinth. Column exhaustive capacity of distilled water spiked chromium shows values of $0.75 \mathrm{mgg}^{-1}$. 


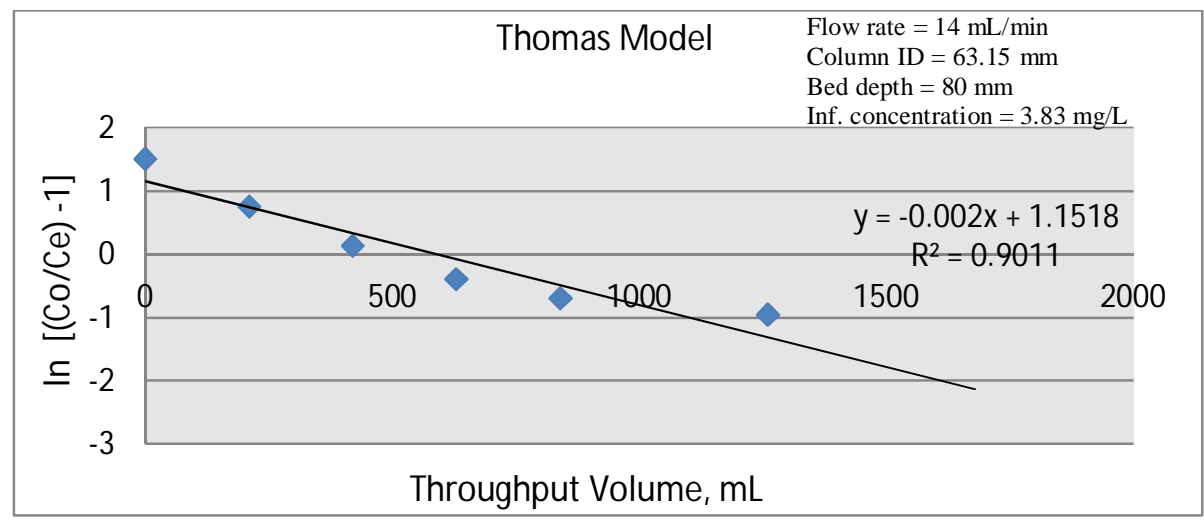

Fig. 17: Column adsorption capacity for chromium by Taro.

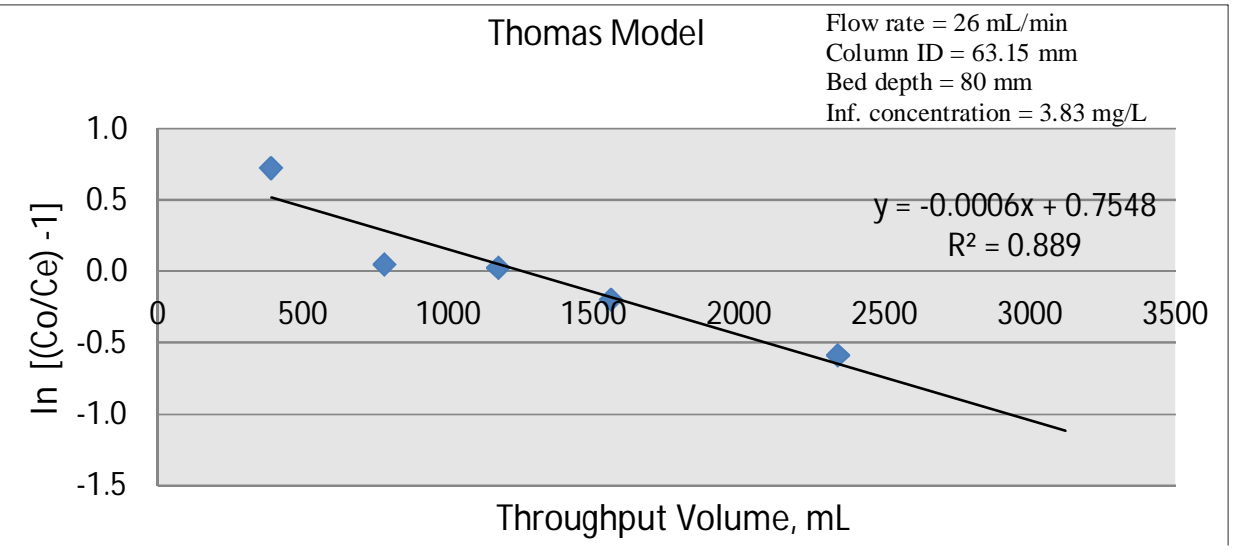

Fig. 18: Column adsorption capacity for chromium by water hyacinth.

\subsection{Column Regeneration and Reuse Studies}

Column desorption studies were subsequently carried out after complete exhaustion of the adsorption column using $0.01 \mathrm{~N} \mathrm{HNO}_{3}$ solution and the metal concentration of the eluate was measured. It is observed from Fig. 19 and Fig. 20 for chromium that the desorption was judged to be successful if the previously adsorbed metal ions were recovered in a volume of less than 1.8 liters of Taro and 3.5 liters of water hyacinth. This result indicates that these biosorbents could be reused in further heavy metal removal treatment from wastewater.

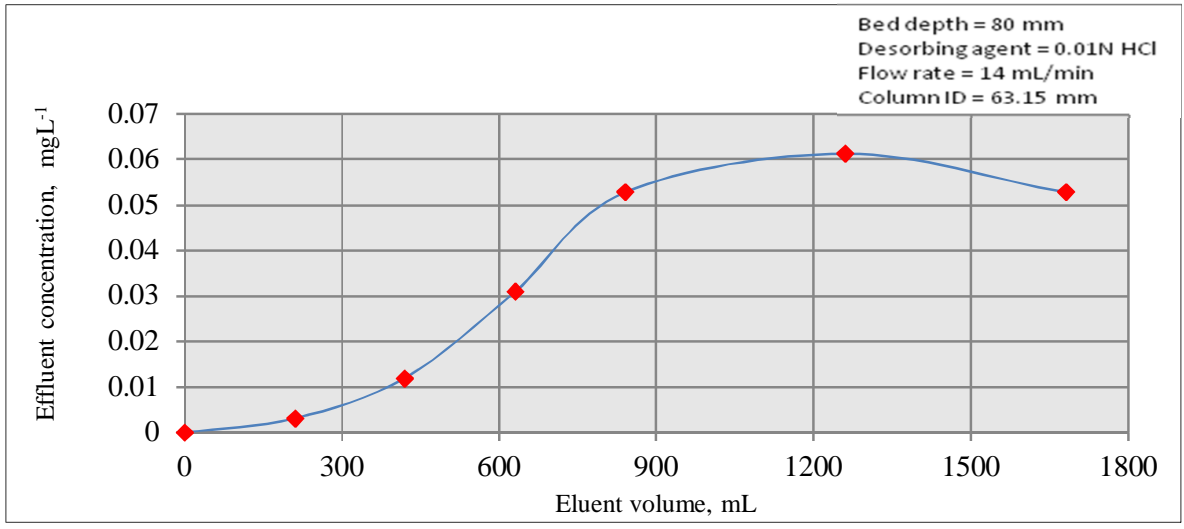

Fig. 19: Desorption of chromium adsorbed Taro. 


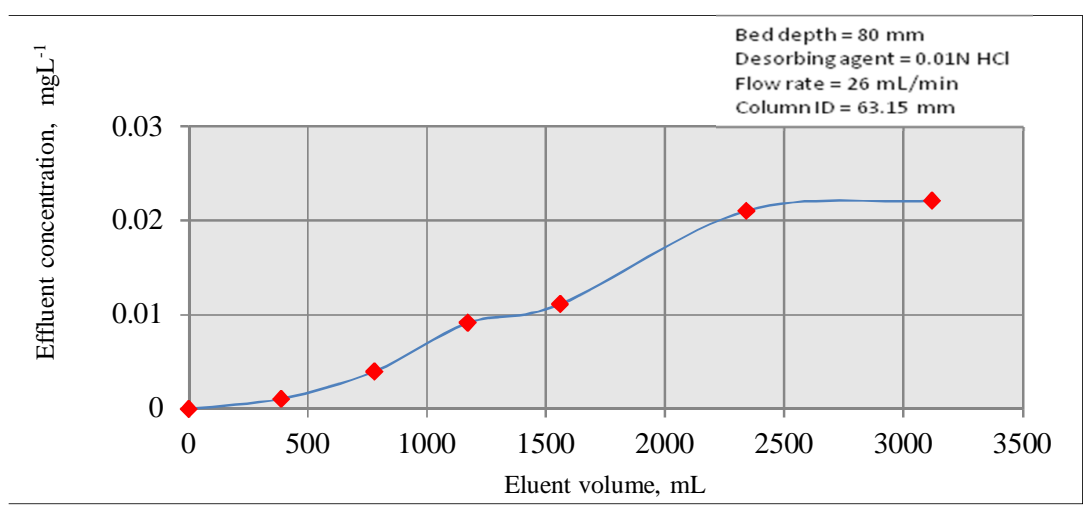

Fig. 20: Desorption of chromium adsorbed water hyacinth.

\section{CONCLUSIONS}

The removal performance of chromium from wastewater using locally available, inexpensive Taro and water hyacinth is quite good. The maximum chromium uptake by Taro and water hyacinth were $1.64 \mathrm{mgg}^{-1}$ and $4.44 \mathrm{mgg}^{-1}$ respectively in batch method. On the other hand, uptake capacity of Taro and water hyacinth in column studies was $1.15 \mathrm{mgg}^{-}$ ${ }^{1}$ and $0.75 \mathrm{mgg}^{-1}$ respectively. The results indicate that both Langmuir and Freundlich isotherms give good correlation of the present data for chromium. In column desorption studies, maximum release of chromium was found after passing $1.8 \mathrm{~L} 0.01 \mathrm{~N} \mathrm{HNO}_{3}$ in Taro and $3.5 \mathrm{~L}$ in water hyacinth. The chromium removal efficiency was significantly influenced by the concentration of $\mathrm{pH}$, adsorbate concentration and adsorbent dose. In view of all these findings, it may be concluded that these biosorbent are very useful, economic, and quite rapid. Therefore, these bisorbent could be successfully used for the removal of chromium from wastewater and many other effluents.

\section{ACKNOWLEDGEMENT}

This work is performed under the financial support of Higher Education and Quality Enhancement Project (HEQEP) CP-259, named, "Industrial Waste Management \& Process Efficiency" of University Grants Commission (UGC) of Bangladesh. Therefore, the authors are grateful to UGC. Moreover, the authors are happy to acknowledge the contribution of the Department of Civil Engineering, Dhaka University of Engineering \& Technology, Bangladesh for allowing the use of their laboratory facilities for experimental work.

\section{REFERENCES}

[1] Ong S, Seng C, Lim P. (2007) Kinetics of adsorption of Cu (II) and Cd (II) from aqueous solution on husk and modified rice husk. EJEAFche., 6(2):1764-1774.

[2] Gupta VK, Ali I. (2004) Removal of lead and chromium from wastewater using bagasse fly ash-a sugar industry waste. J. Colloid and Interface Sci., 271(2):321-328.

[3] Moore JW, Subramaniam R. (2012) Heavy metals in natural waters: Applied monitoring and impact assessment. Springer Science \& Business Media.

[4] Waghmare VH, Chaudhari UE. (2014) Removal of hexavalent chromium from aqueous solution by adsorption on commiphora myrrha bark. Rasayan J. Chem., 7(1): 16-19.

[5] World Health Organization (2004) IARC Working Group on the Evaluation of Carcinogenic Risks to Humans, World Health Organization, and International Agency for Research on Cancer. Betel-quid and Areca-nut Chewing and Some Areca-nut-derived Nitrosamines: IARC Monographs on the Evaluation of Carcinogenic Risks to Human. 
[6] Wing RE, Doane WM, Russell CR. (1975) Insoluble starch xanthate: Use in heavy metal removal. J. App. Pol. Sci., 19(3):847-854.

[7] Huang CP, Ostavic FG. (1978) Removal of Cadmium (II) by activated carbon. J. Envir. Engrg. ASCE, 104(5):863-873.

[8] Huang CP, Wirth PK. (1982) Activated carbon for treatment of cadmium wastewater. J. Envir. Engrg. Div., ASCE, 108(6):1280-1299.

[9] Reed BE, Matsumoto MR. (1993) Modelling Cd adsorption in single and binary adsorbent (PAC) systems. J. Envir. Engrg. Div., ASCE, 119(2):332-348.

[10] Reed BE, Arunachalam S. (1994) Use of granular carbon columns for lead removal. J. Envir. Engg. Div., ASCE, 120(2):416-436.

[11] Srivastava SK, Bhattacharjee G, Sharma AK, Oberoi CK. (1980) studies on the use of inorganic gels in the removal of heavy metals. Water Research, 14:113-115.

[12] Cullen GC, Neil GS. (1982) Removing metals from waste solutions with low rank coals and related materials. Water Research, 16(8):1357-1366.

[13] Bhattacharya AK, Venkobachar C. (1984) Removal of Cadmium (II) by low cost adsorbents. J. Envir. Engg. ASCE, 110:110-127.

[14] Jha IN, Iyengar L, Rao. (1988) Removal of Cadmium using chitosan. J. Envir. Engrg. ASCE, 114(4):962-974.

[15] Chen XH, Gosset T, Thevenot. (1990) Batch copper ion binding and exchange properties of peat. Water Res., 24(12):1463-1470.

[16] Das NC, Bandyopadhyay M. (1991) Removal of lead by vermiculite medium. App. Clay Sci.. 6(3):221-231.

[17] Osman MS. (1995) Biosorption of heavy metals from water environment by macro fungi V. volvacea. Ph. D. Thesis, Indian Institute of Technology, Kharagpur, India.

[18] Martins RJ, Vilar VJ, Boaventura RA. (2010) Removal of Pb (II) from wastewaters by Fontinalis antipyretica biomass: Experimental study and modelling. Desalination and Water Treatment. 20(3):179-188.

[19] Ashraf MA, Mahmood K, Wajid A, Maah MJ, Yusoff I. (2011) Study of low cost biosorbent for biosorption of heavy metals. Int. Conf. Food Eng. Biotechnology, 9:60-68.

[20] Rocha LS, Lopes CB, Borges JA, Duarte AC, Pereira E. (2013) Valuation of unmodified rice husk waste as an eco-friendly sorbent to remove mercury: a study using environmental realistic concentrations. Water, Air, \& Soil Pollution. 224(7):1-18.

[21] Milonjić SK, Bošković MR, Ćeranić TS. (1992) Adsorption of uranium (VI) and zirconium (IV) from acid solutions on silica gel. Sep. Sci. Tech., 27(12):1643-1653.

[22] Nathalie C, Guilet R, Deydier E. (2003) Adsorption of Cu (II) and Pb (II) onto a grafted silica: Isotherms and kinetic models. Water Research, 37(13):3079-3086.

[23] Pandey PK, Sharma SK, Sambi SS. (2010) Kinetics and equilibrium study of chromium adsorption on zeolite NaX. Int. J. Env. Sci. Tech., 7(2):395-404.

[24] Foo K, Hameed BH. (2010) Insights into the modeling of adsorption isotherm systems. Chem. Eng. J., 156(1):2-10.

[25] Rengaraj S, Joo CK, Kim Y, Yi J. (2003) Kinetics of removal of chromium from water and electronic process wastewater by ion exchange resins: $1200 \mathrm{H}, 1500 \mathrm{H}$ and IRN97H. J. Hazardous Mat., 102(2):257-275.

[26] Allen SJ, Mckay G, Porter JF. (2004) Adsorption isotherm models for basic dye adsorption by peat in single and binary component systems. J. Coll. Interface Sci., 280(2):322-333.

[27] Demirbas E, Kobya M, Konukman AES. (2008) Error analysis of equilibrium studies for the almond shell activated carbon adsorption of $\mathrm{Cr}(\mathrm{VI})$ from aqueous solutions. J. Hazardous Mat., 154(1):787-794.

[28] Langmuir I. (1918) J. Am. Chem. Soc., 40:1361.

[29] Weber WJ. (1972) Physicochemical processes for water quality control. Wiley inter science.

[30] Mohammad A, Rafaqat AKR, Siddiqu BA. (1996) Studies on removal and recovery of Cr (V1) from electroplating waste. Water Research, 30(6):1478-1482.

[31] Gupta VK, Gupta M, Sharma S. (2001) Process development for the removal of lead and chromium from aqueous solutions using red mud - an aluminum industry waste. Water Research, 35(5):1125-1134. 
[32] Kavak D, Öztürk N. (2004) Adsorption of boron from aqueous solution by sepirolite: II column studies. Illuslrararasi Bor Sempozyumu, 23:495-500.

[33] Sivakumar P, Palanisamy PN. (2009) Adsorption studies of basic Red 29 by a nonconventional activated carbon prepared from Euphorbia antiquorum L. Int. J. Chem. Tech. Res., 1(3):502-510.

[34] Othman MR, Lee OR, Fernando WJN. (2006) Gas adsorption and surface diffusion on $5^{\circ} \mathrm{A}$ microporous adsorbent in transition and turbulent flow region. IIUM Engineering Journal, $7(1): 1-12$. 